\title{
Wpływ mediów na recepcję wątków społecznych zawartych w przemówieniach papieża Franciszka podczas Światowych Dni Młodzieży w Krakowie
}

\author{
The impact of the media on the reception of social themes \\ in pope Francis' speeches during World Youth Day in Krakow
}

\author{
Wiesław Przyczyna \\ Uniwersytet Papieski Jana Pawła II w Krakowie, \\ Kanonicza 25, 31-002 Kraków, Polska; \\ e-mail: wieslaw.przyczyna@upjp2.edu.pl \\ Aneta Załazińska \\ Wydział Polonistyki, Uniwersytet Jagielloński, \\ ul. Gołębia 16, 31-007 Kraków, Polska; \\ e-mail: aneta.zalazinska@uj.edu.pl
}

\begin{abstract}
Abstrakt
Przeprowadzone na potrzeby artykułu analizy przemówień papieża Franciszka pokazały, że podejmowane przez niego wątki społeczne nie wpłynęły na poglądy Polaków, ani też nie zmieniły ich postaw. Porównując wyniki badań z komentarzami medialnymi, można odnieść wrażenie, że Polacy znacznie bardziej słuchali dziennikarzy niż słów papieża. Powodem tego był fakt, że większość Polaków otrzymywała informacje o papieskiej pielgrzymce z mediów. Wiadomości te zawierały zinterpretowane przez dziennikarzy słowa papieża Franciszka. Oddzielenie wypowiedzi papieskich od dziennikarskich interpretacji to zadanie trudne, które wymaga od odbiorcy czasu i intelektualnego wysiłku. $\mathrm{Z}$ tego powodu Polacy wybierali łatwiejszą drogę, akceptując przedstawiane przez media interpretacje.
\end{abstract}

Słowa kluczowe: papież Franciszek; Światowe Dni Młodzieży w Krakowie; postawy społeczne Polaków; wątki społeczne w nauczaniu papieża Franciszka.

\begin{abstract}
Our analyses have shown that Pope Francis' social teachings did not affect the views of Poles and did not change their attitudes. Comparing them with the media commentaries, one might get the impression that the Poles listened to the journalists rather than the Pope himself. The reason for this was the fact that most Poles got their information about the papal pilgrimage from the media. This information contained Pope Francis' words, but already interpreted by the journalists. Separating these words from their interpretations is a difficult task - it requires intellectual effort and time. Poles therefore chose the easier route - they accepted what the media suggested.
\end{abstract}

Keywords: Pope Francis; World Youth Day in Krakow; social attitudes of Poles; social teaching of Pope Francis. 
W dniach od 26 do 31 lipca 2016 roku odbywały się w Krakowie Światowe Dni Młodzieży. Z tej okazji przebywał w Polsce papież Franciszek. Odwiedził wtedy Kraków, Częstochowę, Auschwitz i Brzegi koło Krakowa. Wygłosił w tym czasie dziesięć przemówień, z czego siedem zawierało ważne wątki społeczne'. Autorów artykułu interesuje, jak wątki te zostały przyjęte przez polskich katolików? Czy miały one wpływ na ich poglądy i postawy? Jaką rolę odegrały w tym media katolickie?

\section{Opis materiału źródłowego}

Materiał źródłowy dla niniejszych badań składa się z fragmentów papieskich przemówień zawierających wątki społeczne oraz wypowiedzi dziennikarzy na ich temat. Wątki społeczne pojawiły się w następujących przemówieniach: 27 lipca na Wawelu podczas oficjalnego powitania i w katedrze wawelskiej na spotkaniu z biskupami, 28 lipca na Jasnej Górze w Częstochowie i na krakowskich Błoniach z okazji pierwszego spotkania z młodzieżą, 29 lipca również na krakowskich Błoniach podczas drogi krzyżowej, 30 lipca w Łagiewnikach oraz w Brzegach. Zebrane razem układają się w cztery bloki tematyczne: 1. historia, pamięć, tożsamość; 2. uchodźcy; 3. pomoc potrzebującym; 4. ochrona życia².

Natomiast teksty dziennikarskie komentujące te wątki pochodzą ze stron internetowych informacyjnych portali katolickich z okresu od 25 lipca do 2 sierpnia 2016 roku, czyli bezpośrednio związanego z przebiegiem Światowych Dni Młodzieży. Do analiz wybrano trzy największe opiniotwórcze portale: deon.pl, fronda.pl i wiara.pl. Wybór tych właśnie portali podyktowany był kilkoma względami. Należą one do największych w swojej kategorii, mają duże społeczne oddziaływanie, choć nie są bezpośrednio powiązane z odpowiednikami prasowymi (w odróżnieniu na przykład od portalu „Tygodnika Powszechnego”, „Gościa Niedzielnego” czy „Naszego Dziennika”) ${ }^{3}$. Są rozpoznawalne przez świeckich internautów, zwłaszcza katolików, w przeciwieństwie do innych witryn katolickich (poczytnych i opiniotwórczych), ale znanych wąskiemu gronu duchownych lub ewentualnie świeckich intensywnie zaangażowanych w życie Kościoła. I to co najważniejsze, portale te charakteryzują się aktualnością informacji, widoczną na stronach głównych. Tutaj też można je porównać z innymi portalami, które wprawdzie są rozpoznawalne w kręgach internautów katolików, ale wiadomości widoczne na ich stronach nie są aktualizowane na bieżąco. W założeniu bowiem informacje te nie mają charakteru newsowego - skupiają się przykładowo na ko-

${ }^{1}$ Pod hasłem przemówienia rozumiemy wystąpienia oficjalne, homilie, rozważania i wypowiedzi spontaniczne.

2 Pełne teksty wymienionych przemówień znajdują się na stronie internetowej Laboratorium Więzi: Franciszek w Polsce. Co powiedział papież podczas Światowych Dni Młodzieży, www.laboratorium.wiez.pl [dostęp: 14.09.2016].

${ }^{3}$ Por. Guzek 2012: 227-240. 
mentarzach czy opiniach dotyczących wybranych wydarzeń. Deon.pl, fronda.pl i wiara.pl to portale, gdzie czas reakcji dziennikarskiej jest niemal natychmiastowy, a wiadomości są opisem codziennych wydarzeń. Tę aktualność można było zauważyć zwłaszcza w czasie trwających Światowych Dni Młodzieży, kiedy każdy etap pielgrzymki papieskiej, związane z tym wydarzenia i co najważniejsze, przemówienia Franciszka podawane były do wiadomości publicznej i opisywane na bieżąco, nawet kilka razy dziennie.

W podanym okresie na stronach tych portali ukazało się wiele tekstów tematycznie związanych z papieską pielgrzymką. Do analizy wybrano wszystkie publikacje o tematyce społecznej ukazujące się na stronie głównej portalu, co gwarantowało również potencjalnie największy ich zasięg. Zakładano przy tym, że portale te z oczywistych powodów będą wspierać papieża Franciszka i jego nauczanie ${ }^{4}$.

\section{Wątki społeczne w przemówieniach papieża Franciszka i w przekazie medialnym}

\subsection{Historia, pamięć, tożsamość}

Pierwsza grupa wątków społecznych łączy się z tematyką historii, pamięci i tożsamości. Papież mówił o nich kilkakrotnie. One też zostały skomentowane przez dziennikarzy na stronach portali katolickich.

\subsubsection{Słowa papieża Franciszka}

Cechą charakterystyczną narodu polskiego jest pamięć. Zawsze byłem pod wrażeniem żywego zmysłu historycznego papieża Jana Pawła II. Gdy mówił o narodach, wychodził od ich dziejów, aby podkreślić ich skarby humanizmu i duchowości. Świadomość tożsamości, wolna od manii wyższości, jest niezbędna dla zorganizowania wspólnoty narodowej na podstawie jej dziedzictwa humanistycznego, społecznego, politycznego, ekonomicznego i religijnego, aby inspirować społeczeństwo i kulturę, zachowując je wiernymi wobec tradycji, a jednocześnie otwartymi na odnowienie i na przyszłość. W tej perspektywie niedawno obchodziliście 1050. rocznicę Chrztu Polski. Było to z pewnością ważne wydarzenie jedności narodowej, które potwierdziło, że zgoda, pomimo różnorodności poglądów, jest pewną drogą do osiągnięcia dobra wspólnego całego narodu polskiego. Także owocna współpraca na płaszczyźnie międzynarodowej i wzajemny szacunek dojrzewają poprzez świadomość i poszanowanie tożsamości własnej oraz innych. Dialog nie jest możliwy, jeśli każdy nie wychodzi od swojej tożsamości (Kraków, Wawel, 27.07.2016 r.).

Także wasza historia, uformowana przez Ewangelię, Krzyż i wierność Kościołowi, była świadkiem pozytywnego wpływu autentycznej wiary, przekazywanej z rodziny

${ }^{4}$ Cytaty pochodzą ze stron głównych następujących portali: deon.pl, fronda.pl, wiara.pl [dostęp: 25.07.-02.08.2016]. 
do rodziny, z ojca na syna, a zwłaszcza przez matki i babcie, którym trzeba bardzo dziękować. [...] Wasz naród pokonał na swej drodze wiele trudnych chwil w jedności. Niech Matka, mężna u stóp Krzyża i wytrwała w modlitwie z uczniami w oczekiwaniu na Ducha Świętego, zaszczepi pragnienie wyjścia ponad krzywdy i rany przeszłości i stworzenia komunii ze wszystkimi, nigdy nie ulegając pokusie izolowania się i narzucania swej woli (Częstochowa, 28.07.2016 r.).

Dzisiaj my, dorośli, potrzebujemy was, byście nas nauczyli żyć razem w różnorodności, w dialogu, w dzieleniu wielokulturowości nie jako zagrożenia, lecz jako szansy: miejcie odwagę nauczyć nas, że łatwiej jest budować mosty, niż wznosić mury! [...] Most, który możemy postawić tu i teraz: uścisk dłoni, podać sobie ręce. [...] To wspaniały most braterski. Oby nauczyli się go stawiać wielcy ludzie tego świata!.. nie dla zdjęcia, gdy podając sobie ręce, myślimy o czymś innym - ale by wciąż budować coraz wspanialsze mosty. Oby ten ludzki most był zaczynem wielu innych; będzie trwałym śladem (Brzegi, 30.07.2016 r.).

Mogą was osądzać, że jesteście marzycielami, bo wierzycie w nową ludzkość, która nie godzi się na nienawiść między narodami, nie postrzega granic krajów jako przeszkody i zachowuje swoje tradycje bez egoizmu i resentymentów. Nie zniechęcajcie się (Brzegi, 31.07.2016 r.).

\subsubsection{Słowa dziennikarzy}

Papież wezwał do jedności, odrzucenia ran przeszłości i krzywd na rzecz pojednania. To zawsze była siła naszego narodu.

[...] papież jest admiratorem tradycyjnej rodziny [...] ponieważ uważa, że tradycyjna rodzina jest niezbędna dla przetrwania świata i przyszłości ludzkości.

Ta wypowiedź to mocne przypomnienie, że w istocie nie ma dialogu tam, gdzie giną tożsamości, gdzie promuje się multi-kulti, wyrzeczenie się własnej tożsamości i zastąpienie jej innymi.

Dzisiejsze kazanie na Jasnej Górze było subtelną medytacją o wierze, ale także mocnym przypomnieniem tego, na czym zasadza się nasza wiara, i jak bardzo konkretna powinna ona być. Franciszek przypomniał choćby, że wiara jest przekazywana w łańcuchu pokoleń.

Odwołując się do historii Polski, papież mówił, że najbardziej dramatyczne momenty przetrwaliśmy, zachowując jedność. Jedność w różnorodności.

[...] nie było tam multi-kulti.

[...] jako naród zjednoczony potrafiliśmy przejść wiele różnych trudności.

[...] podkreślił, że nasza historia uformowana jest przez Ewangelię, krzyż i wierność Kościołowi. 
[Mówił] w jaki sposób Ewangelia wpływa na dzieje narodu polskiego.

Papież patrzy na te 1050 lat naszej historii, widzi wiele krzywd, jakie nam wyrządzono, ale wzywa Maryję, żeby stała się matką stworzenia wspólnoty ze wszystkimi.

[Mówił] w jasny sposób o jedności i przypomina historię Polski.

Papież nie wskazuje winnych, a oczywistym jest, że dobrze wie o bolesnych polskich podziałach, tylko życzy nam, by Matka Boże zaszczepiła w Polakach pragnienie wzniesienia się ponad krzywdy i odniesione rany, aby tworzyć komunię ze wszystkimi.

[...] jedność ponad wszystkimi naszymi podziałami.

[...] zwracał na to uwagę, mówiąc o polskiej historii, którą opisuje jako losy rodzin przekazujących sobie przez pokolenia wartości.

Mamy w Polsce zbyt żywe dziedzictwo chrześcijańskie, by je zastępować jego ludzkimi podróbkami, pełnymi tragicznie ludzkich ambicji.

Dziennikarze zwracają uwagę na pewne wybrane kwestie. I właściwie nie powinno to nikogo dziwić. Niemniej jednak warto zauważyć, jaki jest to wybór. Tożsamość polska definiowana jest jako chrześcijańska, a rodzina jako wielopokoleniowa z tradycjami religijnymi. Pojawiają się komentarze dotyczące pojednania, lecz częściej mówi się o jedności. To znamienne, ponieważ te bliskoznaczne słowa konotują jednak nieco inne odniesienia: jedność to cecha, a więc bierne jej posiadanie lub nie, a pojednanie to czynne działanie lub też wynik tego działania. Zauważalne są także dwa nawiązania do modnego określenia multi-kulti, czyli do wielokulturowości jako czegoś negatywnego. Może to dziwić, gdyż w przemówieniach papieskich nie pojawia się żadna sugestia pejoratywnego rozumienia tego określenia. Co więcej, papież apeluje, by Polacy nauczyli się żyć w różnorodności i traktować wielokulturowość nie jako zagrożenie, ale jako szansę.

\subsection{Uchodźcy}

Papież Franciszek w swoich przemówieniach dużo miejsca poświęcił sprawie uchodźców ${ }^{5}$. Jego słowa na ten temat były też szeroko komentowane na stronach portali katolickich.

\subsubsection{Słowa papieża Franciszka}

Ta ostatnia kwestia [uchodźców] wymaga dodatkowo mądrości i miłosierdzia, aby przezwyciężyć lęki i zrealizować największe dobro. Trzeba zidentyfikować przyczyny emigracji z Polski, ułatwiając powrót osobom, które chcą wrócić. Jednocześnie po-

\footnotetext{
5 Temat uchodźców wystąpił w sześciu przemówieniach.
} 
trzebna jest gotowość przyjęcia ludzi uciekających od wojen i głodu; solidarność z osobami pozbawionymi swoich praw podstawowych, w tym do swobodnego i bezpiecznego wyznawania swojej wiary. Równocześnie należy zabiegać o współpracę i koordynację na poziomie międzynarodowym, w celu znalezienia rozwiązania konfliktów i wojen, które zmuszają wielu ludzi do opuszczenia swoich domów i ojczyzny. Chodzi zatem o uczynienie tego, co w naszej mocy, aby ulżyć ich cierpieniom, niestrudzenie, inteligentnie i stale działać na rzecz sprawiedliwości i pokoju, świadcząc konkretnymi faktami o wartościach humanistycznych i chrześcijańskich. Zachęcam naród polski, aby w świetle swojej tysiącletniej historii patrzył z nadzieją w przyszłość i na problemy, którym musi stawić czoło (Kraków, Wawel, 27.07.2016 r.).

W odniesieniu do imigrantów, powiem, że problem tkwi tam, w ich ojczyźnie. Ale jak ich przyjmiemy? Sądzę, że każdy kraj musi zobaczyć, w jaki sposób i kiedy. Nie wszystkie kraje są równe. Nie wszystkie kraje mają takie same możliwości. [...] Ilu i jak? Nie można dać odpowiedzi uniwersalnej, ponieważ gościnność zależy od sytuacji każdego kraju, a także kultury. Ale oczywiście można zrobić wielkie rzeczy. Na przykład modlitwa: cotygodniowe adoracje Najświętszego Sakramentu (Kraków, katedra, 27.07.2016 r.).

[...] miłosierdzie ma zawsze młode oblicze. Serce miłosierne ma bowiem odwagę, by porzucić wygodę; serce miłosierne potrafi wychodzić na spotkanie innych, potrafi objąć wszystkich. Serce miłosierne potrafi być schronieniem dla tych, którzy nigdy nie mieli domu albo go stracili, potrafi stworzyć atmosferę domu i rodziny dla tych, którzy musieli emigrować, jest zdolne do czułości i współczucia. Serce miłosierne potrafi dzielić swój chleb z głodnym, serce miłosierne otwiera się, aby przyjmować uchodźców oraz imigrantów. [...] Naucz nas jak Marię z Betanii słuchania tych, których nie rozumiemy, tych, którzy pochodzą z innych kultur, innych narodów, a także tych, których się boimy, sądząc, że mogą nam wyrządzić zło (Kraków, Błonia, 28.07.2016 r.).

Darmo otrzymaliśmy, darmo dawajmy. Jesteśmy powołani, aby służyć Jezusowi ukrzyżowanemu w każdej osobie zepchniętej na margines, by dotknąć Jego błogosławionego ciała w człowieku wykluczonym, głodnym, spragnionym, nagim, uwięzionym, chorym, bezrobotnym, prześladowanym, uchodźcy, imigrancie. Tam znajdziemy naszego Boga, tam możemy dotykać Pana (Kraków, Błonia, 29.07.2016 r.).

[...] niech nasza Matka Miłosierdzia uczy nas troszczyć się konkretnie o rany Jezusa w naszych potrzebujących braciach i siostrach, zarówno bliskich jak i dalekich, chorego i migranta (Kraków, Łagiewniki, 30.07.2016 r.).

Pójść na ulice, naśladując „szaleństwo” naszego Boga, który uczy nas spotykania Go w głodnym, spragnionym, nagim, chorym, w przyjacielu, który źle skończył, w więźniu, w uchodźcy i w imigrancie, w człowieku bliskim, który jest samotny (Brzegi, 30.07.2016 r.).

\subsubsection{Słowa dziennikarzy}

Papież nie powiedział wcale, byśmy otworzyli się na uchodźców natychmiast i bezwarunkowo. Mówił o gotowości przyjęcia. 
[...] w obecnych dniach, tuż po krwawych masakrach we Francji i w Niemczech w tym zabójstwie katolickiego księdza! - właśnie przez imigrantów i „uchodźców”, poruszyć ten temat, nawołując do ich przyjmowania, byłoby po prostu... bardzo niezręcznie!

Nie zabrakło także odniesienia do problemu uchodźców. Papież prosił o mądrość i miłosierdzie w podejściu do problemów migracyjnych.

Gościnność zaś i otwarcie powinno zaś dotyczyć nie wszystkich, a tych, którzy uciekają od wojen i głodu, i których prawo do wolności religijnej czy życia jest naruszana. [...] rzeczywistych uchodźców, a nie wszystkich uciekinierów.

Pierwszymi ofiarami radykalnego islamizmu są zaś chrześcijanie. I na ich przyjęcie możemy i powinniśmy być otwarci.

[...] papież rozróżnił sytuację przybywających na Stary Kontynent w celach zarobkowych oraz uchodźców ze stref objętych konfliktami zbrojnymi.

Oto bowiem okazuje się, że papież nie ma też nic przeciwko polskiej postawie wobec imigrantów.

Czy papież powiedział, że potrzebna jest gotowość przyjęcia tych, którzy uciekają od wojen i głodu (ważne: bez wskazania ich wyznania)? Tak.

[...] papieska wypowiedź w odniesieniu do uchodźców miała charakter analityczny. Ojciec św. mówi o gotowości przyjęcia ludzi uciekających od wojen i głodu, co wyraźnie wskazuje na uchodźców. A to nie jest to samo, co emigranci zarobkowi - zauważył.

Bardzo mocne było sformułowanie o otwartości serca na ludzi potrzebujących, na ludzi, którzy uciekają przed wojną, na uchodźców. To wybrzmiało mocno.

[...] papież podkreśla konieczność solidarności z potrzebującymi oraz ochronę życia, co nie odnosi się tylko do uchodźców, ale wszystkich będących w trudnej sytuacji.

[...] każde życie należy chronić, a także przyjmować tych, którzy potrzebują pomocy. Nie odczytuję tych słów tylko w kontekście imigrantów i uchodźców, ale przede wszystkim jako wezwanie do pomocy wszystkim potrzebującym.

[...] nie ma żadnych istotnych różnic między Kościołem w Polsce, wiernymi w naszym kraju, a papieżem Franciszkiem. Główne rozbieżności między Polską a papieskim nauczaniem dostrzegane są w podejściu do tematu uchodźców. Tymczasem polscy biskupi mówią w tej sprawie jednym głosem, podkreślając, że nie można zmienić Ewangelii i że jest oczywiste, że pomoc uchodźcom jest chrześcijańskim obowiązkiem.

[...] papież oprócz wątków duszpasterskich poruszył też problem emigracji.

A jeśli zjawiają się ,kolorowi”, to też problemu nie mamy.

Ksenofobiczne czasy PRL-u dawno minęły, teraz młodzi dogadują się między sobą dość dobrze, często bardzo dobrze. 
Nie dajmy sobie zatem wmówić, że nie lubimy czy boimy się obcokrajowców. Nie dajmy sobie wmówić jakiejś rzekomej ksenofobii. Ani w nią wpędzić.

W przywołanych głosach dziennikarskich bardzo ciekawe są odmienne interpretacje społecznego nauczania papieża. Jedni bezpośrednio przywołują jego słowa o konieczności pomocy uchodźcom, drudzy starają sięje jednak relatywizować. Relatywizacja ta wiąże się z poszukiwaniem, jak się wydaje, usprawiedliwienia dla odmiennych poglądów (rozróżnienia między uciekinierami a emigrantami zarobkowymi), z próbą rozmycia konkretnego apelu o pomoc (sugeruje się, że apel dotyczy wszystkich potrzebujących, a nie tylko uchodźców) lub z niedostrzeganiem problemu (rzekoma ksenofobia).

\subsection{Pomoc potrzebującym}

Następna grupa spraw społecznych poruszonych przez papieża Franciszka wiązała się z pomocą potrzebującym. Sprawom tym wiele uwagi poświęcili również dziennikarze katoliccy na analizowanych stronach portali.

\subsubsection{Słowa papieża Franciszka}

Miłosierdzie ma zawsze młode oblicze. Serce miłosierne ma bowiem odwagę, by porzucić wygodę; serce miłosierne potrafi wychodzić na spotkanie innych, potrafi objąć wszystkich. Serce miłosierne potrafi być schronieniem dla tych, którzy nigdy nie mieli domu albo go stracili, potrafi stworzyć atmosferę domu i rodziny dla tych, którzy musieli emigrować, jest zdolne do czułości i współczucia. Serce miłosierne potrafi dzielić swój chleb z głodnym, serce miłosierne otwiera się, aby przyjmować uchodźców oraz imigrantów. [....] Kiedy serce jest otwarte, jest zdolne do marzeń, bo jest w nim miejsce na miłosierdzie. Jest miejsce na czułość wobec tych, którzy cierpią. [...]

Zaangażuj nas w przygodę budowania mostów i burzenia murów, tak płotów, jak i zasieków. Zaangażuj nas w przygodę spieszenia z pomocą ubogiemu, temu, kto czuje się samotny i opuszczony, kto już nie odnajduje sensu swego życia. [...] Naucz nas jak Marię z Betanii słuchania tych, których nie rozumiemy, tych, którzy pochodzą z innych kultur, innych narodów, a także tych, których się boimy, sądząc, że mogą nam wyrządzić zło (Kraków, Błonia, 28.07.2016 r.).

Darmo otrzymaliśmy, darmo dawajmy. Jesteśmy powołani, aby służyć Jezusowi ukrzyżowanemu w każdej osobie zepchniętej na margines, by dotknąć Jego błogosławionego ciała w człowieku wykluczonym, głodnym, spragnionym, nagim, uwięzionym, chorym, bezrobotnym, prześladowanym, uchodźcy, imigrancie. Tam znajdziemy naszego Boga, tam możemy dotykać Pana. [...] Dziś ludzkość potrzebuje mężczyzn i kobiet, a szczególnie ludzi młodych, takich jak wy, którzy nie chcą przeżywać swojego życia połowicznie, młodych gotowych poświęcić swoje życie w bezinteresownej służbie braciom najuboższym i najsłabszym, na wzór Chrystusa, który oddał się całkowicie dla naszego zbawienia. W obliczu zła, cierpienia, grzechu, jedyną możliwą od- 
powiedzią dla ucznia Jezusa jest dar z siebie, a nawet dar własnego życia, na wzór Chrystusa; to jest postawa służby (Kraków, Błonia, 29.07.2016 r.).

[...] życie Jego najbliższych uczniów, do których grona jesteśmy powołani, składa się z konkretnej miłości, czyli służby i dyspozycyjności; jest to życie, gdzie nie ma przestrzeni zamkniętych i własności prywatnych, dla własnej wygody. [...] Jezus poszukuje serc otwartych i delikatnych wobec słabych - w żadnym wypadku surowych; serc uległych i przejrzystych, które nie udają wobec tych, którzy mają w Kościele zadanie wskazywania drogi.

Niech nasza Matka Miłosierdzia uczy nas troszczyć się konkretnie o rany Jezusa w naszych potrzebujących braciach i siostrach, zarówno bliskich jak i dalekich, chorego i imigranta (Kraków, Łagiewniki, 30.07.2016 r.).

Pójść na ulice, naśladując „,szaleństwo” naszego Boga, który uczy nas spotykania Go w głodnym, spragnionym, nagim, chorym, w przyjacielu, który źle skończył, w więźniu, w uchodźcy i w imigrancie, w człowieku bliskim, który jest samotny (Brzegi, 30.07.2016 r.).

\subsubsection{Słowa dziennikarzy}

Był to też uśmiech w stronę rządzących, bo gdy Franciszek mówi, że do państwa należy pomoc dzieciom, rodzinom, najsłabszym i najuboższym, to obywatele mają świadomość, że obecna władza właśnie pochyla się nad tymi problemami dzięki przełomowym programom prospołecznym.

[...] czy nasze rodziny, nasze państwo są miejscem, gdzie każdy może być przyjęty także ten najsłabszy, może nieoczekiwany, gość, dar.

Jest oczywiste, że ludziom potrzebującym trzeba pomagać, a my w naszym kraju daliśmy przecież pomoc i schronienie, np. Czeczenom.

[...] głowa Kościoła Katolickiego, musi uwrażliwiać wiernych na biedę, na drugiego człowieka w potrzebie i te słowa w ten sposób wybrzmiały.

Radosna, młodzieńcza wiara nie jest naiwna, ale konfrontuje się ze złem i cierpieniem, a z tej konfrontacji ma wypływać zaangażowanie na rzecz ubogich, cierpiących, prześladowanych.

[...] państwo i Kościół powinny brać na siebie trud pomocy społecznej, zwłaszcza w zakresie polityki prorodzinnej.

W tym wypadku dziennikarze również interpretują słowa papieża Franciszka o pomocy potrzebującym. Jedni widzą w nich apel skierowany do Kościoła i państwa jako tych, na których spoczywa obowiązek niesienia pomocy ubogim. Inni rozumieją je jako ukłon w stronę rządzących za promowanie programów prospołecznych. Natomiast niemal wszyscy w swoich komentarzach skrzętnie unikają słów „uchodźca” i ,emigrant”, zastępując je - ich zdaniem - nazwą pojemniejszą, tj. ,potrzebującymi”. 


\subsection{Ochrona życia}

Ważnym wątkiem społecznym papieskich przemówień była ochrona życia. Pojawił się on również na stronach katolickich portali w interpretacji dziennikarzy.

\subsubsection{Słowa papieża Franciszka}

Życie musi być zawsze przyjęte i chronione - zarówno przyjęte jak i chronione - od poczęcia aż do naturalnej śmierci, i wszyscy jesteśmy powołani, aby je szanować i troszczyć się o nie. Z drugiej strony do zadań państwa, Kościoła i społeczeństwa należy towarzyszenie i konkretna pomoc wszystkim, którzy znajdują się w sytuacji poważnej trudności, aby dziecko nigdy nie było postrzegane jako ciężar, lecz jako dar, a osoby najsłabsze i najuboższe nigdy nie były pozostawiane samym sobie (Kraków, Wawel, 27.07.2016 r.).

\subsubsection{Słowa dziennikarzy}

Nietrudno wyczuć, że jest to konkretne wsparcie dla podjętej niedawno inicjatywy zmierzającej do zmiany ustawy aborcyjnej. Papież mówi jasno „nie dla aborcji!

[...] wzywa to do obrony świętości życia od poczęcia, do naturalnej śmierci, do obrony rodziny przed zniszczeniem, które niesie za sobą cywilizacja śmierci, stworzona właśnie przez ideologie lewicy.

[Występuje] jednoznacznie przeciwko aborcji, jak i eutanazji.

[...] Ojciec święty zaapelował dziś do Polaków o pełną ochronę życia ludzkiego.

[...] absolutnie jednoznacznie przypomina, że nie ma wyjątków w obronie życia, że nic i nikt nie może usprawiedliwić zabójstwa prenatalnego.

W te słowa muszą wsłuchać się wszyscy polscy politycy i liderzy opinii [...] Teraz już nikt nie może udawać, że tych słów nie było, że papież ma jakieś wątpliwości.

[...] bardzo jasna wypowiedź papieża na temat ochrony życia, od poczęcia po naturalną śmierć.

Komentarze dziennikarskie dotyczące kwestii ochrony życia są wyraźnie homogeniczne. Apel papieża jest hiperbolizowany, ukonkretniany i dookreślany. Łączy się go z polskim dyskursem politycznym dotyczącym prawnych rozstrzygnięć związanych z przerywaniem ciąży i eutanazją.

Porównanie słów papieża Franciszka, które padły w czasie jego przemówień podczas Światowych Dni Młodzieży, z ich przedstawieniami, interpretacjami i ocenami, jakie pojawiły się na stronach katolickich portali internetowych, poka- 
zuje różnicę między tymi dwoma dyskursami. Katolickie portale internetowe bardzo wyraźnie utwierdzały swoich odbiorców w przekonaniu, że nauki papieskie w żadnym razie nie są rewolucyjne. Papież Franciszek swoimi słowami nie wniósł nic nowego ponad to, co polscy katolicy już wiedzieli i jak się zachowywali. Jego nauki były jedynie przypomnieniem znanych prawd i zasad, które w Polsce od dawna są respektowane.

\section{Odpowiedź Polaków na nauczanie społeczne papieża Franciszka}

Z badań sondażowych przeprowadzonych przez „Rzeczpospolitą” po Światowych Dniach Młodzieży wynika, że słowa papieża Franciszka o historii, pamięci i tożsamości narodowej miały wpływ na 56\% badanych, głównie mieszkańców małych miast (59\%) i wsi (56\%). Jeżeli chodzi o uchodźców, to jedynie 33\% ankietowanych przyznało, że papieskie nauczanie zmieniło ich nastawienie $\mathrm{w}$ tej kwestii. Największą siłę oddziaływania miały słowa papieża o pomocy potrzebującym. Aż 76\% respondentów stwierdziło, że papież Franciszek zmienił ich podejście do tej sprawy. Ponad połowa badanych zadeklarowała, że nauczanie papieskie zmieniło ich stosunek do ochrony życia. Najwięcej było ich wśród osób między 25. a 34. rokiem życia - 63\%, najmniej-39\% u tych w wieku 35-44 lata (Krzyżak 2016: 5).

Jaki stosunek do powyższych wartości mieli Polacy przed Światowymi Dniami Młodzieży w Krakowie? Według CBOS-u 83\% badanych było zdania, że pamięć o przeszłości jest potrzebna współczesnemu człowiekowi, a 51\% czuło się związanych z miejscowością, w której mieszka. Liczba osób niechętnych przyjmowaniu uchodźców w pierwszej połowie 2016 roku wahała się między $60 \%$ a 75\%. Zdecydowana większość Polaków (73\%) starała się w jakiś sposób pomagać potrzebującym. Natomiast za ochroną życia od poczęcia do naturalnej śmierci opowiadało się $38 \%$ ankietowanych ${ }^{6}$.

Porównanie powyższych danych pokazuje, że oddziaływanie nauczania papieskiego w kwestiach społecznych było stosunkowo niewielkie ${ }^{7}$. Wydaje się, że było to spowodowane przede wszystkim tym, iż Polacy w swojej większości informacje o pielgrzymce i nauczaniu papieskim czerpali z mediów. Świadczy o tym sondaż przygotowany przez CBOS w dniach 17-25 sierpnia 2016 roku do-

${ }^{6}$ Dane te są dostępne pod następującymi adresami: Urmański J., Co polskie społeczeństwo uważa na temat aborcji $i$ in vitro?, http://www.bioetyka.krakow.pl/aktualnosci/szczegoly/208/Co_ polskie_spoleczenstwo_uwaza_na_temat_aborcji_i_in_vitro [dostęp: 20.07.2017]; http://www. cbos.pl/PL/publikacje/raporty.php [dostęp: 20.07.2017]; oraz strony, których adresy znajdują się na: http://www.bioetyka.krakow.pl/aktualnosci/szczegoly/208/Co_polskie_spoleczenstwo_uwaza_na_ temat aborcji i in_vitro [dostęp: 20.07.2017].

${ }^{7}$ Brak wpływu nauczania papieskiego podczas Światowych Dni Młodzieży zauważalny jest także w dziedzinie religijności. Z badań wynika, że miało ono wpływ na życie tych, którzy na co dzień są blisko Kościoła. Nie miało ono jednak przełożenia na wzrost religijności w skali społecznej. Por. Sepioł 2017: 36. 
tyczący zainteresowania wizytą papieską w Polsce. Aż 63\% ankietowanych zadeklarowało, że systematycznie śledziło przebieg wizyty Franciszka. W tej grupie prawie połowa ankietowanych zapamiętała jakieś słowa papieża (48\%). Wśród wszystkich ankietowanych taką deklarację złożyło 37\%, co można uznać za wysoki wskaźnik - ponad 1/3 Polaków (niezależnie od wyznania czy deklaracji światopoglądowych) zapamiętała fragment z przemówień Franciszka wygłoszonych w Polsce.

Ciekawie przedstawia się także układ tematów, które przykuły największą uwagę odbiorców przemówień Franciszka. Najwyższe wskaźniki zainteresowania (które należy rozumieć jako tematy zapamiętane) przypadły apelowi o pomoc potrzebującym (13\%), następnie - przyjmowaniu uchodźców (12\%) oraz problematyce życia małżeńskiego i rodzinnego $(11 \%)^{8}$.

Ale nie tylko czerpanie informacji z mediów miało wpływ na recepcję papieskiego nauczania o kwestiach społecznych, lecz także sam sposób funkcjonowania tych mediów. Charakterystyczną cechą wszystkich mediów jest troska o zgodność propagowanych treści z nastawieniem społecznym. Innymi słowy, media przekazując i filtrując informacje, starają się zaspokoić oczekiwania odbiorców ${ }^{9}$. Tak też było z nauczaniem społecznym papieża Franciszka. Dziennikarze z katolickich portali internetowych starali się nauczanie to dostosować do potrzeb swoich odbiorców. Dlatego w kwestiach spornych łagodzili wypowiedzi papieża Franciszka, zastępując słowa kłopotliwe innymi, bardziej neutralnymi. Tam, gdzie jego słowa były zbyt radykalne, osłabiali je, dokonując ich dekontekstualizacji. A w sytuacjach skrajnych, gdy nauczanie to było niezgodne z poglądami odbiorców, posuwali się nawet do jego negowania.

Inną istotną cechą mediów jest ich kreatywność. Oznacza to, że media nie tylko odpowiadają na zainteresowanie odbiorców, ale to zainteresowanie wzbudzają, podsycają lub gaszą. Tak widziane są kreatorami - mówią, o czym mamy myśleć i w jaki sposób. Tym bardziej poprzez sposób podawania wiadomości, relacjonowania i komentowania ich, sugerują, podsuwają, a wielokrotnie narzucają opinie odbiorcom. Oddziaływanie takie charakteryzuje nie tylko media tradycyjne (prasę, radio czy telewizję), ale i media cyfrowe, których przestrzenią działania jest Internet. Do takich z pewnością zaliczają się rozmaite portale informacyjne, które mają swoich specyficznych odbiorców, tzn. takich, którzy tylko z nich czerpią informacje o świecie. Niezależnie jednak od charakterystyki danego typu medium, jego siła oddziaływania nie ulega wątpliwości ${ }^{10}$.

Ostatnią cechą mediów zasługującą na podkreślenie z racji niniejszych analiz jest subiektywizm w relacjonowaniu wydarzeń. Zwraca na to uwagę W. Lippman:

\footnotetext{
${ }^{8}$ Por. Sondaż dla Polskiego Radia, [PAP] Ilu Polaków śledziło przebieg wizyty papieża podczas ŚDM? Sondaż CBOS, http://www.polskieradio.pl/5/3/Artykul/1664619,Ilu-Polakow-sledzilo-przebieg-wizyty-papieza-podczas-SDM-Sondaz-CBOS [dostęp: 10.10.2016].

${ }^{9}$ Por. Goban-Klass 2002: 129.

10 Szeroko na ten temat: Kozłowska 2006.
} 
„Żadna relacja określonego wydarzenia nie odzwierciedla rzeczywistości. Każde jego ujęcie przez obserwatora stanowi interpretację"11. Nie jest zatem obojętne, w jakim kontekście dane słowa są cytowane, w jaki sposób przedstawiane i jak komentowane. Nawet najbardziej obiektywne streszczenia przemówień nie są wolne od subiektywnego wyboru cytatów, podkreślania jednych i pomijania innych słów. Jedynym niewartościującym sposobem relacji jest zamieszczenie całego przemówienia dokładnie w takiej postaci, w jakiej zostało wygłoszone. Media rzadko jednak sięgają po ten model. Z różnych oczywiście względów, także czysto technicznych.

Przeprowadzone analizy pokazały, że nauczanie społeczne papieża Franciszka nie wpłynęło na poglądy Polaków i nie zmieniło ich postaw. Porównując je z komentarzami medialnymi, można odnieść wrażenie, że Polacy słuchali raczej dziennikarzy niż samego papieża. Było to spowodowane tym, że większość Polaków informacje o papieskiej pielgrzymce czerpała $\mathrm{z}$ mediów. Publikacje te wprawdzie zawierały słowa papieża Franciszka, ale już zinterpretowane przez dziennikarzy. Oddzielenie ich od tych interpretacji jest zadaniem dość trudnym wymaga intelektualnego wysiłku i czasu. Polacy zatem wybrali drogę łatwiejszą - przyjęli to, co zaproponowały im media.

\section{Bibliografia}

Dorenda-Zaborowicz M., 2013, Nowe media w stużbie marketingu politycznego, w: Nowe media a praktyki komunikacyjne, red. K. Pokorna-Ignatowicz i in., Kraków, s. 36-62.

Goban-Klass T., 2002, Media i komunikowanie masowe. Teorie i analizy prasy, radia, telewizji i Internetu, Warszawa-Kraków.

Guzek D., 2012, Konwergencja mediów katolickich w Polsce, w: Konwergencja mediów masowych i jej skutki dla wspótczesnego dziennikarstwa, t. 2, red. M. Gierula, P. Szostok, Katowice, s. 227-240.

Katolickie portale informacyjne: deon.pl, wiara.pl, fronda.pl [dostęp: 25.07.-02.08.2016].

Kozłowska A., 2006, Oddziaływanie mass mediów, Warszawa.

Krzyżak T., 2016, Papież grochem o ścianę, „Rzeczpospolita”, 17 sierpnia, s. 5.

Laboratorium Więzi: Franciszek w Polsce. Co powiedziat papież podczas Światowych Dni Młodzieży, www.laboratorium.wiez.pl [dostęp: 14.09.2016] .

[PAP] Ilu Polaków śledzito przebieg wizyty papieża podczas ŚDM? Sondaż CBOS, http:// www.polskieradio.pl/5/3/Artykul/1664619,Ilu-Polakow-sledzilo-przebieg-wizyty-papieza-podczas-SDM-Sondaz-CBOS [dostęp: 10.10.2016].

Sepioł M., 2017, Bunt dwukierunkowy, „Tygodnik Powszechny”, nr 25, s. 36-38.

${ }^{11}$ Cyt. za: M. Dorenda-Zaborowicz 2013: 51. 
Urmański J., Co polskie społeczeństwo uważa na temat aborcji i in vitro?, http://www. bioetyka.krakow.pl/aktualnosci/szczegoly/208/Co_polskie_spoleczenstwo_uwaza na_temat_aborcji_i_in_vitro [dostęp: 20.07.2017]. 